\title{
Valorization of Organic Wastes by Composting Process and Soil Amendment
}

\author{
Hafedh Rigane and Khaled Medhioub \\ Unité de Recherche: Etude et gestion des Environnements côtier et urbain, \\ University of Sfax \\ Tunisia
}

\section{Introduction}

Agricultural wastes disposal is becoming a serious environmental problem. Indeed, these residues may be highly polluting and phytotoxic. The removal of the produced solid and liquid residues is causing serious environmental problems. The direct application of organic wastes, such as olive husks or olive mill wastewaters, to soil has been considered as an inexpensive method of disposal in addition to the recovery of their mineral and organic components. Nevertheless, due to their ligno-cellulosic contents, olive husks are potentially environmentally harmful biomass. Fresh olive husks (not biologically stabilized) may have phytotoxicity due to their monogenic chemical composition (only lignin and cellulose), to phenols coming from olive oil processing, to its high Carbon/Nitrogen $(\mathrm{C} / \mathrm{N})$ ratio and to the presence of hormon inhibitors (De Bertoldi et al., 1986). According to several authors (De Jager et al., 2001; Palm et al., 2001), the improvement of soil fertility mainly under low input agricultural systems requires the input of stabilized or mature organic wastes. Many studies (Gallardo-Lara and Nogales, 1987; He et al., 1992; Ouédraogo et al., 2001; Stamatiadis et al., 1999) have shown that application of mature composts at reasonable rates improves plant growth, soil physical properties and increases available soil nutrient levels.

Composting in a controlled biooxidative process that involves a heterogeneous organic solid substrate may resolve this problem. It evolves through a thermophilic stage and the temporary release of phytotoxins, leading to the production of carbon dioxide, water, mineral salts and stabilized organic matter containing humic like substances. These kinds of fertilizers are used to improve soil fertility and plant production either in organic and conventional agriculture.

The main problems that can occur from excessive application of compost are plant toxicity due to salt content (Stamatiadis et al., 1999) and accumulation in plants of trace metals which may pose a health risk when humans or farm animals consume the plant (Petruzzelli, 1996; Cabrera et al., 1989).

Many wastes produced in important quantities are used for composting process such as solid wastes (olive husk, poultry manure) and also liquid wastes mainly the olive mill wastewaters which may be transformed into an organic fertilizer by composting. This is an inexpensive method of disposal leading to important advantages. The composted olive 
husks are organic fertilizers that improved soil fertility (Fiestas Ros de Ursinos, 1986; Tomati and Galli, 1992). The olive husk composts bring essentially potaasium (K), in addition to Nitrogen $(\mathrm{N})$, Phosphorus $(\mathrm{P})$ and Magnesium $(\mathrm{Mg})$ and obviously organic matter $(\mathrm{OM})$. Soil amendment with compost enhances its microbial activity and improves its physical and chemical properties. Thus, farmer's interest for recycling organic wastes in agriculture as fertilizers or amendments is increasing. The composting studies were performed on olive husks mixed ( $80 \%$ ) with $20 \%$ poultry manure. The initial mixture was realized in order to reach a $\mathrm{C} / \mathrm{N}$ ratio of 30 . The obtained compost was characterized physically and chemically in order to define its fertilizing capacities and use safety.

The objectives of the present work were to assess the suitability of a waste compost to supply some essential plant nutrients such as $\mathrm{N}, \mathrm{P}, \mathrm{K}$, iron (Fe), manganese (Mn), zinc (Zn) and copper $(\mathrm{Cu})$; evaluate and compare the effects of manure and compost on soil chemical properties of studied soils in the same zone and to prove the effect of compost on crop productivity.

\section{Composting process}

The composting in a controlled biooxidative process that involves a heterogenous organic substrate in the solid state that evolves through a thermophile stage and the temporary release of phytotoxins, leading to the production of carbon dioxide, water, mineral salts and stabilized organic matter containing humic like substances. By using this method, it is possible to transform olive residues mixed with poultry manure into organic fertilizers with no toxicity to improve soil fertility and plant production.

In this work, we presented examples of solid and liquid wastes chosen in composing essays.

\subsection{Solid wastes}

The raw materials (olive husks) characterized by high organic carbon, very low nitrogen and important ash contents, were co-composted with poultry manure containing high nitrogen and ash rates (Table 1, Hachicha et al., 2003). Two combinations of sifted or non sifted olive husks mixed with poultry manure at 8:2 ratio were selected (Hachicha et al., 2003). The sifting operation was performed using a densimetric method that allows its separation into $40 \%$ pulp and $60 \%$ stone fragments. The latter was used as a substitute for raw olive husks in the role of energy supplier. The sifting was retained to compare the qualities of composts (produced from materials with or without sifting) and to test the possibility of utilization of olive husks without sifting to reduce treatment price. In fact, two windrows were constructed one for each formula.

\subsubsection{Preparation of windrows}

Windrow 1, composed by a mixture of non sifted olive husks and poultry manure and windrow 2 composed by a mixture of sifted olive husks and poultry manure. These will produce respectively compost $\mathrm{C} 1$ and compost $\mathrm{C} 2$. The windrows had triangular shape with $3 \mathrm{~m}$ wide of the base and 2-3 m high. Each windrow was constituted of 10 tons of the mixture. Olive husks are characterized by a very high $\mathrm{C} / \mathrm{N}$ ratio due to high carbon and low nitrogen contents. The olive husks are mainly composed of lignin and cellulose fibres with 
other chemical elements at low concentrations (Vlyssides et al., 1996). The direct application of these solid wastes in soil causes problems because of their phytotoxicity (De Bertoldi and al., 1983). The sifting operation uses a densymetric method that allows their separation into $40 \%$ pulp and $60 \%$ some fragments. The sifted olive husk compost gives more nitrogen and more synthesised and polymerised humic acids than unsifted olive husk compost (Hachicha, 2002; Hachicha and al., 2003). Poultry manure contain relatively high concentrations of total nitrogen (more than $2.5 \%$ of dry matter), of ash (more than $40 \%$ of dry matter) and relatively low $\mathrm{C} / \mathrm{N}$ ratio (Table 1 ).

During the composting process several parameters were followed such as temperature, $\mathrm{pH}$, electrical conductivity (EC) and ash ratio. Maturity was evaluated by the determination of the $\mathrm{C} / \mathrm{N}$ ratio, cation exchange capacity (CEC) and humic acid concentrations (Mustin, 1987). Moreover, during the composting process, moisture was kept at $45-50 \%$ by adding water and aeration was assured by windrow turning. Temperatures were measured daily basis at different positions in the core of windrow using mercury thermometers and the average of all measurements was recorded. Samples for analysis were collected weekly at different points along the windrows.

\begin{tabular}{|l|c|c|c|c|c|}
\hline Component & $\begin{array}{c}\text { Non sifted } \\
\text { olive husks }\end{array}$ & $\begin{array}{c}\text { Sifted olive } \\
\text { husks }\end{array}$ & $\begin{array}{c}\text { Poultry } \\
\text { manure }\end{array}$ & $\begin{array}{c}\text { Windrow } \\
1\end{array}$ & $\begin{array}{c}\text { Windrow } \\
2\end{array}$ \\
\hline $\mathrm{pH}$ & 4.92 & 4.73 & 8.62 & 6.43 & 7.27 \\
\hline E.C. $(\mathrm{mmhos} / \mathrm{cm})$ & - & - & - & 0.5 & 0.68 \\
\hline $\mathrm{C} / \mathrm{N}$ & 48.74 & 37.5 & 10.44 & 32 & 28.5 \\
\hline $\mathrm{CEC}(\mathrm{meq} / 100 \mathrm{~g}$ OM) & - & - & - & 73.56 & 92.93 \\
\hline $\begin{array}{l}\text { Ash content }(\% \text { dry solid } \\
(\text { d.s. }))\end{array}$ & 5.22 & 10.77 & 41.65 & 24.5 & 30.2 \\
\hline Total Kjeldhal N (\%d.s.) & 1.06 & 1.31 & 2.88 & 1.5 & 1.56 \\
\hline Total Organic C (\%d.s.) & 51.67 & 49.13 & 30.08 & 48 & 44.5 \\
\hline Cellulose $(\%$ d.s.)" & 39.75 & 28.09 & 23.17 & 18.6 & 13.9 \\
\hline Lignin $(\%$ d.s.) & 24.72 & 18.73 & 17.15 & 14.3 & 12.2 \\
\hline polyphenols $(\%$ d.s.) & 0 & 0 & 0 & 0.435 & 0.18 \\
\hline Fatty substances (\%d.s.) & 4.08 & 4.29 & 0.8 & 3.02 & 3.67 \\
\hline Total P (\%d.s.) & 0.1 & 0.13 & 1.51 & 0.4 & 0.42 \\
\hline Total K (\%d.s.) & 0.59 & 0.71 & 2.98 & 0.97 & 1.06 \\
\hline Mg (\%d.s.) & 0.08 & 0.10 & 0.50 & 0.15 & 0.23 \\
\hline Ca (\%d.s.) & 0.14 & 0.17 & 6.52 & 1.66 & 2.13 \\
\hline Na (\%d.s.) & 0.21 & 0.29 & 3.58 & 1.32 & 1.25 \\
\hline
\end{tabular}

Table 1. Properties of the initial solid wastes and mixtures (Hachicha et al., 2003).

\subsubsection{Soil amendment}

For amendment tests, we applied two types of composts: compost 1 and compost 2. The essays were realized in plots and in field. 
Cultures have been achieved in plots containing $15 \mathrm{Kg}$ of soil situated in a zone characterized by arid climate. The prepared plots are distributed in sets of 9 units:

- $\quad$ a control set with only a contribution of manure (100\% manure);

- ten sets have been reserved to combinations of different percentages in manure and in composts either 1 or 2 .

Every test set includes 9 plots, four of which have been condemned during the analysis cycle. The various plots controlled during the production cycle permitted to follow the beginning of the tuberization and the development of different plant tubers.

We applied compost and poultry manure (PM) in different percentages: 100\% C.1 (Compost 1), $50 \%$ C. 1 or C. $2+50 \%$ PM (Compost 1 or Compost 2 mixed with manure in same quantities), $75 \%$ C. 1 or C. $2+25 \%$ PM (Compost 1 or Compost 2 mixed with manure at $75 \% / 25 \%$ ), $25 \%$ C.1 or C. $2+75 \%$ PM (Compost 1 or Compost 2 mixed with manure at $25 \% / 75 \%$ ), $200 \%$ C.1 or C.2 (the quantity of applied compost is double compared to $100 \%$ ) and $100 \%$ PM ( poultry manure).

In field experiment, the compost was applied soil harvested with tomato cultures (Rio Grande variety) realized in three experiment soils of the same zone. The region is characterized by calcimagnesic soils characterized by calcareous parent rock containing in most cases active lime. The compost retained for tests is the compost 1 which was applied on soil and where studies (Hachicha et al., 2003) showed its agronomic interest. In fact, these authors recorded the same potato yield with both composts, the agronomic field test showed that the sifted olive husk compost (compost 2) acted more positively on the tuber size of potato whereas the non sifted olive husk compost (compost 1) was more beneficial to the plant height and to the leaf weight. In addition, the compost 1 was prepared without sifting the starting materials. In order to improve the soil fertility and to valorise olive husks, tests of amendments by the composts have been exercised on some soil types in this region.

In order to evaluate the quality of soils amended with cow manure and those amended by the compost of olive husks, samples of soils have been appropriated for determination of textural classification, $\mathrm{pH}$, electric conductivity, total lime, active lime, organic matter, organic carbon, total nitrogen, $\mathrm{C} / \mathrm{N}$ ratio, major elements $(\mathrm{Ca}, \mathrm{Mg}, \mathrm{P}, \mathrm{K})$ and trace elements. Analyses were also realized on leaves of tomato to test the similarity between compost and manure and to testify their values referring to World fertilizer use manual (Halliday and Trenkel, 1992).

\subsubsection{Crop production}

The assessment of the agronomic quality of produced composts has been achieved through potato cultures (Spunta variety) in plots and tomato cultures in field experiment. The compost is applied on soils by spreading of 40 tons/ha (the same dose is applied for manure in this zone).

\subsubsection{Evolution of composting process}

The principal parameters controlling composting process are $\mathrm{pH}$, Electric conductivity, temperature, cation exchange capacity (CEC), $\mathrm{C} / \mathrm{N}$ ratio. 


\section{- Temperature}

The data related to the effect of temperature on the composting process indicate that optimum decomposition takes place between 55 and $60^{\circ} \mathrm{C}$ (Morel et al., 1984). For both windrows, high core temperatures $\left(60-70^{\circ} \mathrm{C}\right)$ remained for three months in windrow 2 and for four months in windrow 1 . The presence of more easily biodegradable compounds in the sifted olive husks (material 2) and an important fraction of cellulose and lignin in raw material 1, could explain the difference showed in the thermophilic phase length. The characteristics of composts were shown in table 2 .

\section{- $\mathrm{pH}$ evolution}

The $\mathrm{pH}$ variation ranged from 6.5 to 8 , which consists to aerobic composting (Gardena and Wang, 1981). Nevertheless, for both analysed windrows, $\mathrm{pH}$ slightly decreased over the first two weeks and gradually increased during the active phase for each substrats with a trend towards stabilization. The initial drop in $\mathrm{pH}$ has been reported by other authors (De Bertoldi and al., 1983; Hardy and Sivasithamparam, 1989; Sikora and Sowers, 1983) and is considered to be a consequence of the acid-forming bacteria activity which breaks down complex carbonaceous material to organic acid intermediates. However, the products formed are readily consumed and simultaneous protein degradation starts releasing basic compounds which increase the $\mathrm{pH}$ (Godden and Penninck, 1990). In both windrows, the $\mathrm{pH}$ showed a progressive increase (slightly more rapid for 1) with similar behaviour. For both produced composts, $\mathrm{pH}$ remained at alkaline levels.

\section{- $\quad$ Electric conductivity (EC)}

For both windrows, EC rose progressively. This increase, which took place especially during higher temperatures, may be attributed to the important mineralization that liberates ions. No significant difference was observed between the two windrows. After 150 composting days, E.C. for each final product was $1.5 \mathrm{~ms} \mathrm{~cm}^{-1}$ against 0.8 for the unsifted olive oil processing solid residue.

\section{- Maturity assessment}

We have chosen $\mathrm{C} / \mathrm{N}$ ratio and cation exchange capacity (CEC) as indicators of maturation progress. However, a large number of parameters were tested by different authors (Morel and al., 1984; Stentiford and Pereira, 1985). The aerobic fermentation produces an important quantity of $\mathrm{CO}_{2}$ noted here by a decrease in organic carbon content. Nitrogen constitutes the second most important element after carbon in the composting process. Over the composting cycle, the Kjeldahl nitrogen concentration (Table 2) increased. For final products, nitrogen content was about $2.5 \%$ dry solid. Increases in total nitrogen have also been reported during the composting of sludge and animal manure (Bernal et al., 1996; Tikia et al., 1998). In addition, to the weight losses due to the strong degradation of carbon compounds, a small nitrogen increase during composting could be attributed to fixing bacteria (Jodice and Nappi, 1986) or to inorganic nitrogen immobilizing phenomenon (Tam and Tikia, 1999). Consequently, the decrease of the $\mathrm{C} / \mathrm{N}$ ratio (Table 2) during composting was mainly caused by the loss of carbon concentrations and the accumulation of nitrogen. Stability was reached within three months for the unsifted husks and two months for the sifted material. In both cases, the $\mathrm{C} / \mathrm{N}$ ratio remained around 13 after 150 days of 
composting. During the composting process, microbial activity permitted the increase of cation exchange capacity and humic acid contents (Bernal et al., 1996; Tikia et al., 1998).

\begin{tabular}{|l|c|c|c|}
\hline Elements & Compost 1 & Compost 2 & Manure \\
\hline $\mathrm{pH}$ & 8.51 & 8.44 & 8 \\
\hline organic matter (\% dry matter) & 40.1 & 40.25 & 43.5 \\
\hline $\mathrm{C} / \mathrm{N}$ & 13.65 & 13.32 & 16.9 \\
\hline Nitrogen (\%dry matter) & 1.87 & 2.10 & 2.00 \\
\hline $\mathrm{P}(\mathrm{ppm})$ & 4891 & 6830 & 4600 \\
\hline $\mathrm{K}(\mathrm{ppm})$ & 10660 & 12190 & 10250 \\
\hline $\mathrm{Ca}(\mathrm{g} / \mathrm{l})$ & 21.43 & 22.57 & 16.4 \\
\hline $\mathrm{Mg}(\mathrm{ppm})$ & 5472 & 7747 & 3800 \\
\hline
\end{tabular}

Table 2. Comparison of fertilizing values of composts 1 and 2.

An increase in CEC (cation exchange capacity) values was observed from the beginning of the composting process. Stabilization was reached five months later. In final products, the CEC recorded was about $140 \mathrm{meq} / 100 \mathrm{~g}$ organic matter for compost 1 and $150 \mathrm{meq} / 100 \mathrm{~g}$ organic matter for compost 2, against about $176 \mathrm{meq} / 100 \mathrm{~g}$ for manure. The mass of potato obtained in different plots were observed in figure 3 which showed a significant differences between the effects of composts 1 and 2 . In fact, all plots amended with compost 1 showed potato masses less than $84 \mathrm{~g}$, whereas in plots amended with compost 2, the potato masses exceed $260 \mathrm{~g}$ (Figure 1).

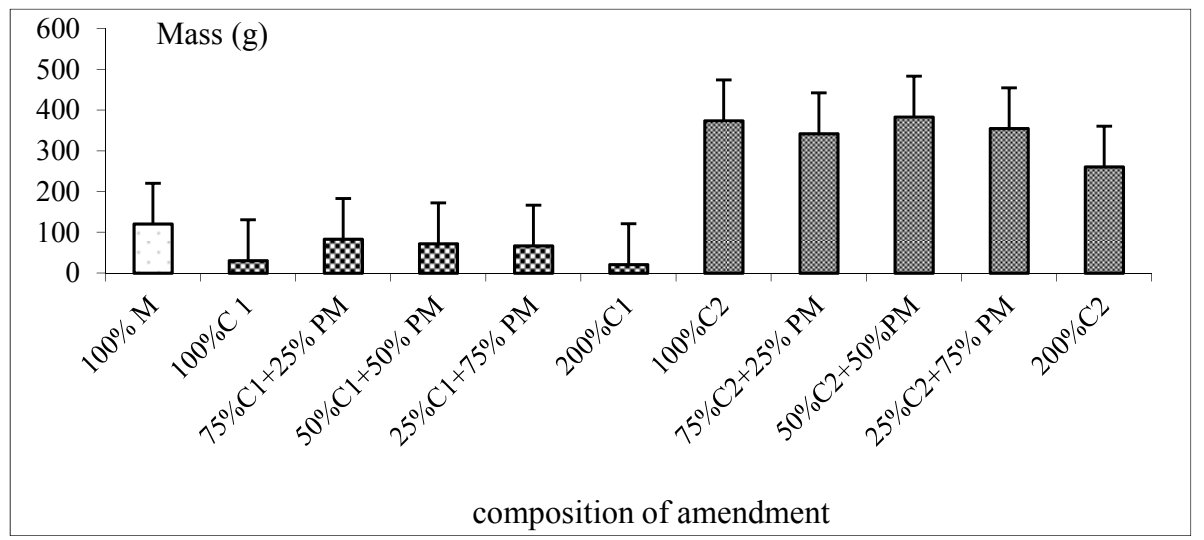

Fig. 1. Mass of potato obtained in different plots.

In field experiment, the productivity of cultivated soils amended with compost 1 which was chosen for economic reasons by removal of sifting operation is presented in Figure 2. The high productions were recorded in soils 2 and 3 amended with compost. This fact is explained by the positive roles of clay and active lime which permit to organic matter retention in soil, and also the role of compost which permits to produce more fertilizing elements related to starting materials. 


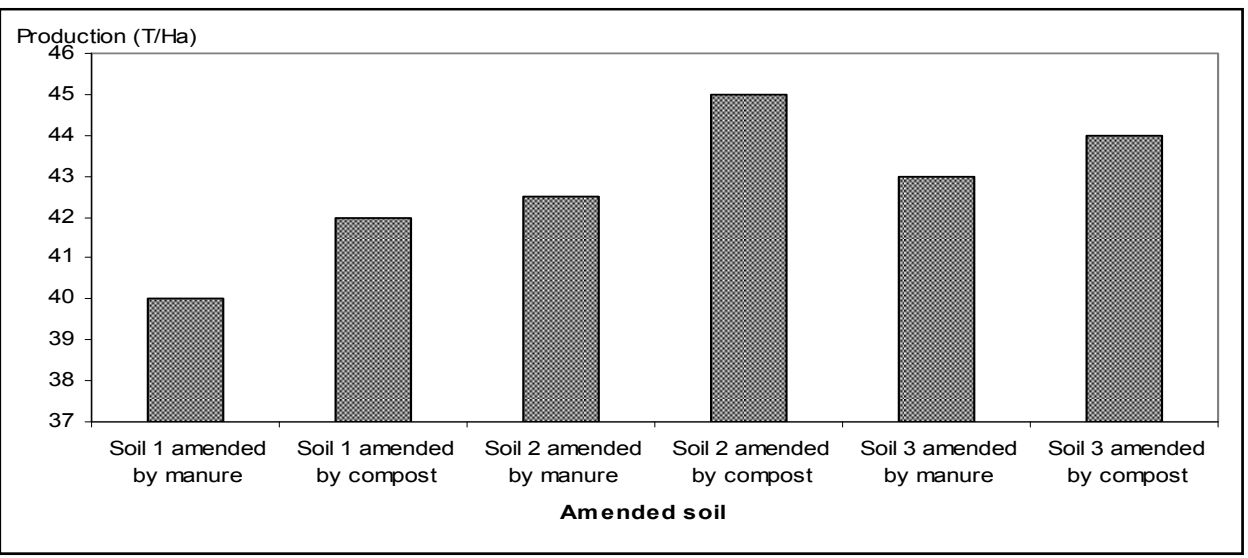

Fig. 2. Soil productivity in different soils.

Clay tenor and organic matter were more important in soil 2 amended by compost, whereas active lime was recorded only in soil 3 (Table 3) (Rigane and Medhioub, 2010). This parameter is important in soil which causes quickly the immobility of the soluble precursors and by the transformation of unsoluble components (such as lignin) caused by an active biological activity, developed with aerated structure in constructed clods of clay-humus$\mathrm{CaCO}_{3}$ (Duchaufour, 1997).

\begin{tabular}{|l|c|c|c|c|c|c|}
\hline Parameters & $\begin{array}{c}\text { Soil 1 } \\
\text { amended } \\
\text { with } \\
\text { compost }\end{array}$ & $\begin{array}{c}\text { Soil 1 } \\
\text { amended } \\
\text { with } \\
\text { compost }\end{array}$ & $\begin{array}{c}\text { Soil 2 } \\
\text { amended } \\
\text { with } \\
\text { compost }\end{array}$ & $\begin{array}{c}\text { Soil 2 } \\
\text { amended } \\
\text { with } \\
\text { compost }\end{array}$ & $\begin{array}{c}\text { Soil 3 } \\
\text { amended } \\
\text { with } \\
\text { compost }\end{array}$ & $\begin{array}{c}\text { Soil 3 } \\
\text { amended } \\
\text { with } \\
\text { compost }\end{array}$ \\
\hline Clay (\%) & 11 & 15 & 10 & 18 & 12 & 14 \\
\hline Sand (\%) & 69 & 66 & 59 & 44 & 63 & 55 \\
\hline Silt (\%) & 20 & 19 & 31 & 38 & 25 & 31 \\
\hline pH & 7.77 & 7.85 & 7.83 & 7.91 & 8.19 & 8.14 \\
\hline EC (mmhos/cm) & 11.43 & 8.42 & 10.2 & 9.82 & 1.87 & 1.85 \\
\hline Total lime (\%) & 4.6 & 5.3 & 3.4 & 2.7 & 21.6 & 25.7 \\
\hline Active lime (\%) & - & - & - & - & 2.7 & 4.2 \\
\hline Organic carbon (\%) & 0.74 & 0.62 & 0.7 & 0.87 & 0.58 & 0.78 \\
\hline Organic matter (\%) & 1.2 & 1.07 & 1.2 & 1.5 & 1 & 1.34 \\
\hline C/N & 12.33 & 10.68 & 11.66 & 11.6 & 11.6 & 11.6 \\
\hline Total Nitrogen (\%) & 0.06 & 0.058 & 0.06 & 0.075 & 0.05 & 0.067 \\
\hline Available P (ppm) & 169 & 166 & 174 & 108 & 58 & 101 \\
\hline Available K (ppm) & 225 & 180 & 294 & 235 & 140 & 150 \\
\hline Fe (\%) & 4.7 & 3.5 & 2.7 & 3 & 2.2 & 2.5 \\
\hline Zn (\%) & 0.97 & 0.82 & 0.65 & 0.56 & 0.4 & 0.4 \\
\hline Cu (\%) & 0.37 & 0.35 & 0.28 & 0.31 & 0.26 & 0.25 \\
\hline Mn (\%) & 1.2 & 1 & 0.98 & 0.85 & 0.72 & 0.65 \\
\hline
\end{tabular}

Table 3. Soil analyses (Rigane and Medhioub, 2010). 
Compared to normal ranges in leaves (Halliday and Trenkel, 1992), the leaves in vegetables in all experiment soils grown under temperate conditions were considered as normal (Table 4) (Rigane and Medhioub, 2010). In fact, the application of composts in experimental soils showed no negative effect on tomato crop. Nevertheless, Basing on deficiency levels presented by Halliday and Trenkel (1992), the leaves vegetables in amended soils showed deficiency in N, P and K elements.

\begin{tabular}{|l|c|c|c|c|c|c|c|}
\hline Elements & $\begin{array}{c}\text { Soil 1 } \\
\text { amended } \\
\text { with } \\
\text { compost }\end{array}$ & $\begin{array}{c}\text { Soil 1 } \\
\text { amended } \\
\text { with } \\
\text { manure }\end{array}$ & $\begin{array}{c}\text { Soil 2 } \\
\text { amended } \\
\text { with } \\
\text { compost }\end{array}$ & $\begin{array}{c}\text { Soil 2 } \\
\text { amended } \\
\text { with } \\
\text { manure }\end{array}$ & $\begin{array}{c}\text { Soil 3 } \\
\text { amended } \\
\text { with } \\
\text { compost }\end{array}$ & $\begin{array}{c}\text { Soil 3 } \\
\text { amended } \\
\text { with } \\
\text { manure }\end{array}$ & $\begin{array}{c}\text { Normal } \\
\text { Ranges in } \\
\text { leaves* }\end{array}$ \\
\hline $\mathrm{N}(\%)$ & 3.1 & 3.15 & 3.1 & 3.17 & 3.18 & 3.14 & $2.9-4.9 \%$ \\
\hline $\mathrm{P}(\%)$ & 0.19 & 0.15 & 0.12 & 0.13 & 0.2 & 0.17 & $0.4-0.7 \%$ \\
\hline $\mathrm{K}(\%)$ & 1.2 & 1.3 & 1 & 1.2 & 1.2 & 1 & $2.7-5.9 \%$ \\
\hline $\mathrm{Ca}(\%)$ & 3.2 & 3 & 3 & 3 & 3.5 & 3.3 & $2.4-7.2 \%$ \\
\hline $\mathrm{Fe}(\mathrm{ppm})$ & 63 & 75 & 62 & 60 & 57 & 48 & $101-291 \mathrm{ppm}$ \\
\hline $\mathrm{Zn}(\mathrm{ppm})$ & 38 & 23 & 39 & 27 & 37 & 31 & $20-85 \mathrm{ppm}$ \\
\hline $\mathrm{Mn}(\mathrm{ppm})$ & 29 & 30 & 27 & 32 & 0.28 & 35 & $55-220 \mathrm{ppm}$ \\
\hline $\mathrm{Cu}(\mathrm{ppm})$ & 6.5 & 6.1 & 5.8 & 5 & 7.3 & 6.1 & $10-16 \mathrm{ppm}$ \\
\hline
\end{tabular}

* World Fertilizer Use Manual (1992)

Table 4. Leaf analysis (Rigane et Medhioub, 2010).

\subsection{Liquid wastes}

The amounts of liquid wastewaters such as olive mill wastewaters (OMW) which is produced in Mediterranean countries are important in the world. Olive oil production has normally been concentrated in the Mediterranean basin countries: Spain, Portugal, Italy, Greece, Turkey, Tunisia and Morocco. These seven countries alone account for $90 \%$ of world production. The high content of mineral salts and the presence of organic compounds, such as fatty acids and polyphenols in the OMW generate difficulties of their disposing and utilization of large amounts of this liquid. The disposal and treatment of this liquid waste are the main problems of the olive oil industry because of its high organic load and content of phytotoxic and antibacterial phenolic substances, which resist to biological degradation (Aktas et al. 2001). The beneficial effects are linked to its high nutrients concentration, especially $\mathrm{K}$, and its potential for mobilizing soil ions, while, negative effects are associated with its high mineral salt content, acidity with low $\mathrm{pH}$ and the presence of phytotoxic compounds, mainly polyphenols (Paredes et al. 1999). Besides, other authors have observed negative effects on plants and soil properties when OMW is used directly as an organic fertiliser (Sierra et al. 2001; Casa et al. 2003; Cereti et al. 2004).

The treatment of OMW and their disposal are becoming a serious environmental problem. Different methods were used based on thermal concentration, physical and chemical and 
biological treatments of the OMW as well as their direct application to agricultural soils as a fertilizer have been widely tested.

The Composting technology is a biological process used for treatment of organic wastes to obtain organic soil fertilisers (Mustin, 1987). Composting experiments with OMW showed that OMW needed lignin-cellulosic wastes as bulking agents and other materials as a nitrogen source for its suitable composting, so that the phytotoxicity could be eliminated and a final product with stabilised and humified organic matter obtained by several authors (Tomati et al. 1995; Vlyssides et al. 1996; Paredes et al. 2000; Paredes et al. 2005). The objective of thist work was to study the effects of OMW on the composting of organic wastes and the behaviour of the compost obtained on soil properties.

\subsubsection{Composting operation}

To study the possibility of treatment of OMW by composting, two piles were prepared by mixing olive husks $(\mathrm{OH})$ with poultry manure (PM) and both humidified with confectionery wastewaters $(\mathrm{CWW})$. Olive mill wastewater $(\mathrm{OMW})$ was added to one pile (pile 1).

The $\mathrm{OH}$ are characterized by the high values of dry matters, $\mathrm{C} / \mathrm{N}$ ratio, calcium and magnesium contents. The $\mathrm{PM}$ is characterized by relatively high $\mathrm{pH}$, mineral matter, phosphorus and potassium. As liquid effluent, the confectionery wastewaters showed the relatively high humidity, electric conductivity, organic matter, nitrogen and sugars. The OMW was acidic ( $\mathrm{pH} 5.3)$ with conductivity $\left(20 \mathrm{mSm}^{-1}\right)$ and important concentrations of $\mathrm{N}$, $\mathrm{P}$ and $\mathrm{K}$ and organic matter (OMW is characterized by black color) and high content of phenolic compounds (8900 $\mathrm{mg} \mathrm{l}^{-1}$ ). The OMW used in the present study were obtained from a OMW disposal site in the city of Agareb in Sfax region (Southern Tunisia), which derived from olive oil production plants.

The piles presented the following compositions:

Pile 1: Olive husks $(\mathrm{OH})(75 \%)+$ Poultry Manure $(\mathrm{PM})(25 \%)+$ Confectionery wastewaters $(\mathrm{CWW})+$ Olive Mill Wastewaters (OMW). The final result after composting constitutes compost C1. The volumes of CWW and OMW used were similar $\left(2.8 \mathrm{~m}^{3}\right.$ for each wastewater).

Pile 2: Olive husks $(\mathrm{OH})(75 \%)+$ Poultry Manure $(\mathrm{PM})(25 \%)+$ Confectionery wastewaters $(\mathrm{CWW})$. The final result after composting constitutes compost $\mathrm{C} 2$. The volume of $\mathrm{CWW}$ used was $5.6 \mathrm{~m}^{3}$.

\section{- Temperature}

The air blowing was stopped during the compost maturity period (6 months). In fact, OM degradation was greater in pile 1 in the mixture with OMW which may be explained by the longer thermophilic phase for this pile. The temperature increased quickly at the beginning of the process to thermophilic values, reaching the maximum level $\left(68^{\circ} \mathrm{C}\right)$ (Figure 3 ).

In both piles, the temperature was maintained between 60 and $70{ }^{\circ} \mathrm{C}$ for about 100 days, which will contribute to the transformation of highly polymerized substrate (lignin and cellulose) by thermophilic microorganisms and also to the hygienisation of the end- 
product (compost) due to pathogen, weed and seed reduction. When the temperature started to decrease, the piles were turned in order to improve both the homogeneity of the material and the fermentation process. The thermophilic phase $\left(\mathrm{T}>40^{\circ} \mathrm{C}\right)$ lasted approximately 105 and 120 days for mixtures 2 and 1, respectively. The biooxidative phase of composting was considered finished when the temperature of the piles was stable and close to that of the atmosphere. This occurred after 180 and 160 days in piles 1 and 2 , respectively.

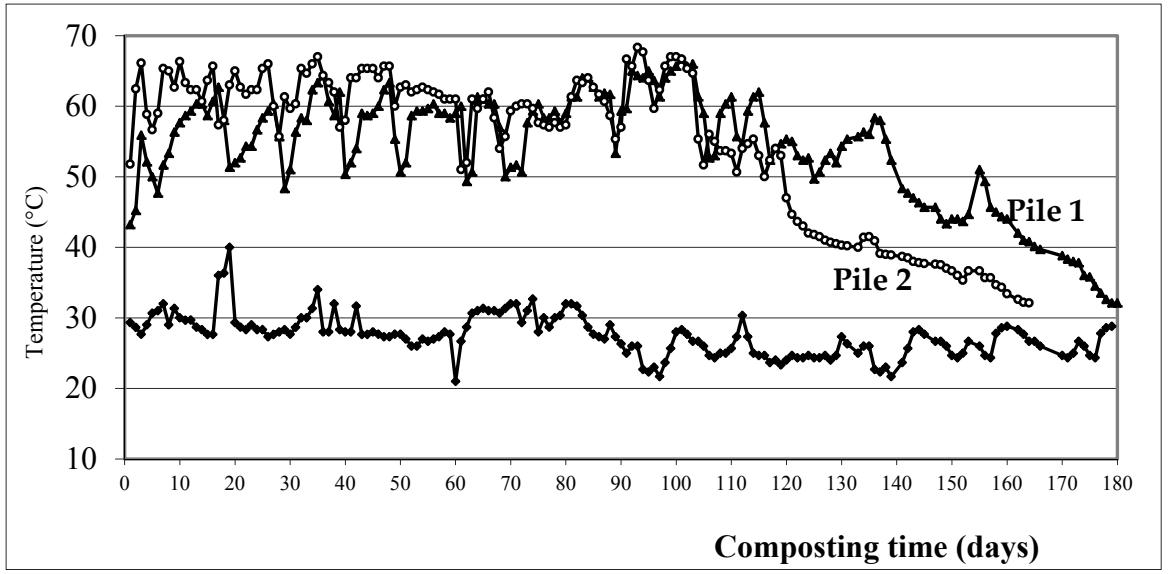

Fig. 3. Temperature evolution during composting process of studied piles (Rigane and Medhioub, 2011).

\section{- Organic matter evolution}

The initial OM concentrations were approximately equal in both piles (Table 2). However, OM degradation was more important in the mixture without OMW (pile 2), which may be due to the longer thermophilic phase for this pile (Figure 4). According to Paredes et al. (2005), this fact can be explained by the higher content of easily degradable organic compounds provided by OMW. 


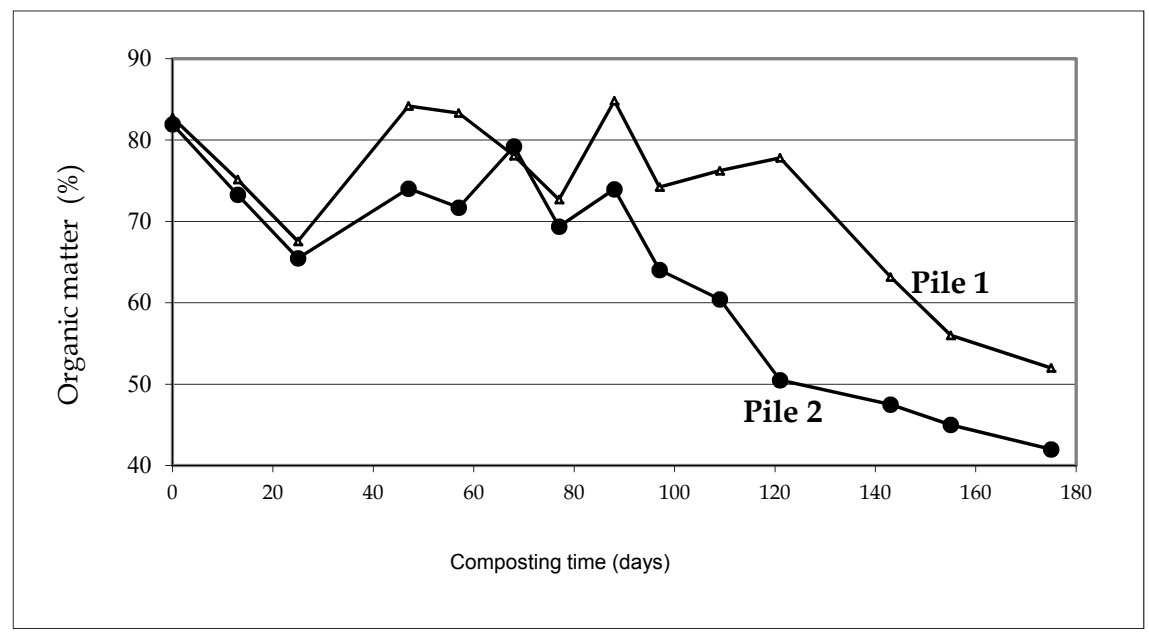

Fig. 4. Organic matter evolution during composting process (Rigane and Medhioub, 2010).

The difference between two composts can be attributed to the higher content of easily degradable organic compounds provided by OMW. OM decomposition bring about an increase in $\mathrm{pH}$ and EC in the piles, as recorded by Paredes et al. (2005), which was explained as a consequence of the degradation of acid-type compounds, such as carboxylic and phenolic groups, the mineralisation of compounds, such as proteins, amino acids and peptides, to ammonia and the relative increased concentration of ions, due to the loss of pile weight. This fact was observed in the higher $\mathrm{pH}$ and electrical conductivity of both composts in comparison to manure (Table 5). The EC in the compost prepared with OMW (C1) was more important than manure (M) and C2 without OMW which can be explained by the high soluble salt content provided from OMW.

This observation can explain the significant difference in the humification ratio $\left(\mathrm{C}_{\mathrm{HA}} / \mathrm{C}_{\mathrm{FA}}\right)$ between composts and manure (Table 5). Respect to organic matter humification, a higher humification ratio was recorded in $\mathrm{C} 2$ without OMW. Therefore, a positive correlation was observed between CEC and $\mathrm{C}_{\mathrm{HA}} / \mathrm{C}_{\mathrm{FA}}$ (Rigane et Medhioub, 2011). In fact, the CEC was more important in compost C2 prepared without OMW which it reached $255 \mathrm{meq} / 100 \mathrm{~g}$, while in compost C1 with OMW, it had 237 meq/100g. Both composts, particularly C1 with OMW, had high levels of macronutrients, especially $\mathrm{K}$ and $\mathrm{Ca}$ (Table 5), compared with those found in manure. Moreover, a higher EC was recorded in composts than manure and mainly in the OMW compost. This was probably linked to the soluble salts contained in OMW. 


\begin{tabular}{|l|c|c|c|}
\hline Parameters & Manure & $\begin{array}{c}\text { Compost C1: } \\
\text { OH+PM+ } \\
\text { CW+OMW }\end{array}$ & $\begin{array}{c}\text { Compost C2: } \\
\text { OH+PM+ CW }\end{array}$ \\
\hline $\mathrm{pH}$ & 8 & 8.34 & 8.61 \\
\hline $\begin{array}{l}\text { Electric conductivity } \\
(\mathrm{mS} / \mathrm{cm})\end{array}$ & 4.55 & 5.46 & 5.18 \\
\hline Total organic carbon $(\%)$ & 33.82 & 27.47 & 22.37 \\
\hline Organic matter $(\%)$ & 63.25 & 52.24 & 42.40 \\
\hline C/N & 16.93 & 11.75 & 13.56 \\
\hline Total Nitrogen $(\%)$ & 2.15 & 1.56 & 1.32 \\
\hline CEC $($ meq/100 g) & 215 & 237 & 255 \\
\hline C $\mathrm{HA} / \mathrm{C}_{\mathrm{FA}}$ & 0.64 & 0.88 & 2.35 \\
\hline Ca (ppm) & 16400 & 68604 & 40869 \\
\hline $\mathrm{Mg}(\mathrm{ppm})$ & 3800 & 5289 & 4347 \\
\hline $\mathrm{K}(\mathrm{ppm})$ & 10250 & 25200 & 23314 \\
\hline $\mathrm{P}(\mathrm{ppm})$ & 4600 & 8539 & 7184 \\
\hline
\end{tabular}

Table 5. Physical and chemical characteristics of manure and two types of composts.

\section{- Soil amendment essay}

In soils amended with two composts were recorded a higher fertilizing values than those amended with manure (Table 6). Tomati et al. (1996), in an experiment with potato grown on soil amended by compost or manure mixtures, obtained higher crop yields with OMW compost.

\begin{tabular}{|l|c|c|c|}
\hline Amendment & Manure & Compost C1 & Compost C2 \\
\hline Potato yield production $(\mathrm{T} / \mathrm{Ha})$ & 42.5 & 46 & 47 \\
\hline
\end{tabular}

Table 6. Comparative effects of composts 1 (C1) and 2 (C2) on potato yield production.

The soil analysis showed that the addition of compost produced great changes in soil $\mathrm{pH}$. This observation was also deduced by Gallardo-Lara and Nogales (1987) in a calcareous soil amended with solid waste compost.

In addition, the studied composts increased significantly the soil salinity, according to the EC values. In the most cases, the increases of Corg, Norg, P and K nutrient contents and the CEC values in soil due to organic amendment were also observed in soils with composts.

The levels of chlorides and sodium were for all time higher in the soils with composts and manure. The Corg, Norg, and available K concentrations and the CEC values of the amended soils decreased after cropping compared to value before cropping for each parameter. This fact is considered as a consequence of the OM mineralisation, plant uptake and fixation of phosphorus as calcium phosphates hardly available to plants in calcareous 
soils (Bernal et al. 1993). However, these parameters were increased significantly by the organic amendment type, particularly with composts. The increases of Corg, Norg and plant-available nutrient contents and CEC values in soil amended with organic fertilisation were also observed by Cabrera et al. (1997), in study of effects of applications of OMW sludge compost. After cropping the compost C1 prepared with OMW showed a residual organic content more important than manure and compost $\mathrm{C} 2$. Besides, $\mathrm{Mg}$ and $\mathrm{P}$ contents were more important in soil amended with $\mathrm{C} 1$ with OMW.

\section{Conclusions}

With the vast amounts of olive and poultry residues production in Mediterranean countries, their treatment and disposal are becoming a serious environmental problems. An attention has been paid to wastes and technologies are available nowadays for reducing their pollutant effects and for their transformations in a final product which can be used without any pollution risk. By using composting technologies, it is possible to transform these residues mixed with appropriate percentages into organic fertilizers (composts) with no phytotoxicity to improve soil fertility and plant production.

The composting of liquid or solid organic agro-industrial wastes offers an important advantages: valorization of wastes, reducing the decrease of farm manure used for soil amendment and absence of negative effects on crop qualities.

The composting is a controlled biological process which involves a heterogeneous organic solid substrate may resolve the problem of wastes which can be liquid or solid.

This technology could have an important repercussion in many countries of the world, since they suffer water restrictions and the increase of organic waste volumes. Thus, it requires new environmental and economically viable management options. In this work, we were interested in agricultural valorisation of composts obtained by mixtures of olive husks, poultry manure, Olive mill wastewaters,...

It can be deduced that composting is a suitable alternative for the recycling wastes. The obtained compost had a stabilised and humified organic matter and an important tenors of macronutrients which were recorded due to OM mineralization. The positive effects on soil fertility and productivity increased with the application of compost. However, the composting of organic wastes depends on raw materials. In fact, the composting of wastes containing OMW for example requires a longer time and this could be the major concern regarding the use of compost in soil with sufficient maturity.

\section{References}

Aktas, E.S., Imre, S. Ersoym, L. (2001). Characterization and lime treatment of olive mill wastewater. Water Research Vol. 35, pp. 2336-2340.

Bernal, M.P., Navarro, A.F., Roig, A, Cegarra, J. and Garcia, D. (1996). Carbon and nitrogen transformation during composting of sweet sorghum bagasse. Biol. Fert. Soils, 22, 141-148.

Cabrera, F, López, R., Martín, P. \& Murillo, J.M. (1997). Aprovechamiento agronómico de composts de alpechín. Frutic Prof. Vol. 88, pp. 94- 105. 
Casa, R., D’Annibale, A., Pieruccetti, F., Stazi, S.R., Giovannozzi Sermanni, G. \& Lo Cascio, B. (2003). Reduction of the phenolic components in olive-mill wastewater by an enzymatic treatment and its impact on durum wheat (Triticum durum Desf) germinability. Chemosphere; Vol. 50, pp. 959- 66.

Cereti, CF, Rossini, F, Federici, F, Quaratino, D, Vassilev, N \& Fenice, M. (2004). Reuse of microbially treated olive mill wastewater as fertiliser for wheat (Triticum durum Desf). Bioresour. Technol., Vol.91:135- 40.

De Bertoldi, M., Vallini, G. and Pera, A. (1983). The biology of composting. Waste management and research. 1, 157-176.

De Bertoldi, P.F., Filippi, C. \& Picci G. (1986). Olive residue composting. Waste management and research. 1, 157-176.

De Jager et al., 2001. A. De Jager, D. Onduru, M.S. Van Wijk, J. Vlaming \& G.N. Gachini , Assessing sustainability of low external input farm management systems with the nutrient monitoring approach: a case study in Kenya. Agric. Syst. 69 (2001), pp. 99 118.

Duchaufour, P.1997. Abrégé de Pédologie : sol, végétation, environnement. Ed. Masson, 291p.

Fiestas Ros de Ursinos, J. A. (1986). Vegetation water used as a fertilizer. In International Symposium on Olive By products Valorization. ed. FAO. Madrid, Spain, pp. 321-330.

Gallardo-Lara, F. \& Nogales, R. (1987). Effect of the application of town refuse compost on the soil plant system. Biol. Wastes 19, pp. 35-62.

Gardena, P. R. and Wang, L. K. (1981). Handbook for environmental engineering. Publ. By Humana press, Clifon, N.J.

Hachicha, R., Rigane, H., Ben Khodher, M., Nasri, M. \& Medhioub, K. (2003). Effects of partial stone removal on the co-composting of olive-oil processing solid residues with poultry manure and the quality of compost. Environmental technology, vol.24. pp. 59-67.

Halliday D.J. \& Trenkel M.E. (1992). World fertilizer use manual. International fertilizer industry association. $632 \mathrm{p}$.

Hardy, G.E. and Sivasithamparam, K. (1989). Microbial, chemical and physical changes during composting of a eucalyptus. In Biol. ferti. Soils 8. 260-270.

Jodice, R. and Nappi, P. (1986). Microbial aspects of compost application in relation to mycorrhizae and nitrogen fixing microorganisms. In compost : production quality and use, edited by De Bertoldi M. and Manios, B.I. (1979). Investigation for soil conditioner production from olive oil processing soild residues. Ph D Thesis. Agriculture University of Athens, Department of Agricultural Biology and Biotechnology.

He, X.T., Traina, S.J. \& Logan, T.J. 1992. Chemical properties of municipal solid waste composts. J. Environ. Qual. 21 (1992), pp. 318-329.

Morel, J.L., Colin, F., Germon, J.C., Godin, P. \& Juste, C.(1984). Methods for the evaluation of the maturity of municipal refuse compost. In composting of agricultural and other wastes. Edited by Gasser J.K.R., CEC Workshop, pp.56-72.

Mustin, M. (1987). Le compost: gestion de la matière organique. Ed. François Dubusc. Paris. 973 p. 
Ouédraogo, E., Mando, A. \& Zombré, N.P. (2001). Use of compost to improve soil properties and crop productivity under low input agricultural system in West Africa. Agric. Ecosyst. Environ. 84, pp. 259-266.

Palm, A.C., Gachengo, C.N., Delve, R.J., Cadisch, G. \& Giller, K.E. (2001). Organic inputs for soil fertility management in tropical agroecosystems: application of an organic resource database. Agric. Ecosyst. Environ. 83. pp. 27-42.

Paredes, C., Cegarra, J., Roig, A., Sa'nchez-Monedero, M.A. \& Bernal, M.P. (1999). Characterization of olive-mill wastewater (alpechin) and its sludge for agricultural purposes. Bioresource Technology Vol.67, pp.111-115.

Paredes, C., Roig, A., Bernal, M.P., Sanchez-Monedero, M.A. \& Cegarra, J., (2000). Evolution of organic matter and nitrogen during co-composting of olive mill wastewater with solid organic wastes. Biology and Fertility of Soils 32, 222-227.

Paredes, C, Cegarra, J, Bernal MP \& Roig A. (2005). Influence of olive mill wastewater in composting and impact of the compost on a swiss chard crop and soil properties. Environment international. Vol.31, pp. 305-312.

Petruzzelli, G. 1996. Heavy metals in compost and their effect on soil quality. In: M. De Bertoldi, P. Sequi, B. Lemmes and T. Papi, Editors, The composting science part I, Blackie Academic and Professional Editor, Glasgow, pp. 212-223.

Rigane H. \& Medhioub K.(2010). Effects of amendment of calcimagnesic soils with olive husk compost in Tunisia. Compost Science and Utilization. Vol.18, N4, pp. 249254.

Rigane H. \& Medhioub K.(2011). Co-composting of olive mill wastewaters with manure and agro-industrial wastes. Agricultural valorisation of composts obtained (Tunisia, Northern Africa). In Press in Compost Science and Utilization.

Stamatiadis, S., Werner, M. \& Buchanan, M.(1999). Field assessment of soil quality as affected by compost and fertilizer application in a broccoli field (San Benito County, California). App. Soil Ecol. 12, pp. 217-225.

Sierra, J., Marti, E., Montserrat, G., Cruanas, R. \& Garau, M.A. (2001). Characterisation and evolution of a soil affected by olive oil mill wastewater disposal. Sci. Total Environ. Vol. 279, pp. 207-214.

Sikora, L. J. and Sowers, M. A. (1983). Factors affecting the composting process. In Proceedings of the international conference on composting of soild wastes and slurries. Leeds, U.K.

Stentiford, E.I. and Pereira Neto, T. J. (1985). Simplified systems for refuse/sludge compost. Biocycle, vol 26, N5, pp.46-49.

Tam, N.F.Y. and Tikia, S.M. (1999). Nitrogen transformation during co-composting of spent pig manure, sawdust litter and sludge under forced aeration. Env. Techn. Vol. 20, pp. 259-267.

Tikia, S.M., Tam, N.F.Y. and Hodgkiss,Y. (1998). Changes in chemical properties during composting of spent litter at different moisture content. Agric. Ecosyst. Environ. 67, 79-89.

Tomati, V. \& Galli, E. (1992). The fertilizing value of waste waters from the olive processing industry. In Humus et Plunta Proceedings. ed. Elsevier Science, B.V. Amsterdam, The Netherlands, pp.107-126. 
Tomati, U, Galli, E, Pasetti, L \& Volterra, E. (1995) Bioremediation of olive-mill wastewaters by composting. Waste Management Res. Vol. 13, pp. 509-518.

Tomati, U., Galli, E., Fiorelli, F.\& Pasetti, L. (1996). Fertilizers from composting of olive-mill wastewaters. International Biodeterioration and Biodegradation Vol. 44, pp. 155-162.

Tsikalas, E.P. (1985). Enrichment olive oil processing residues with nurients for using as a soil conditioner. Ph D Thesis. Agriculture University of Athens, Department of Agricultural Biology and Biotechnology.

Vlyssides, AG, Bouranis, DL, Loizidou, M. \& Karvouni, G. (1996). Study of a demonstration plant for the co-composting of olive-oil-processing wastewater and solid residue. Bioresour Technol., Vol. 56, pp. 187-193. 


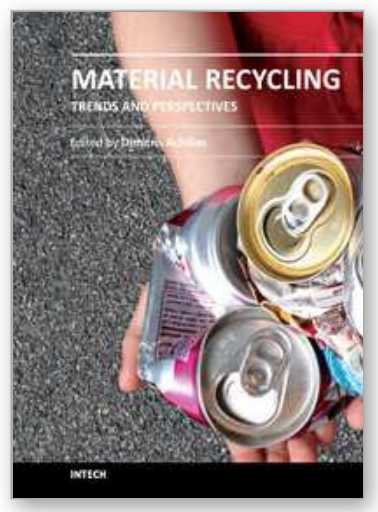

\author{
Material Recycling - Trends and Perspectives \\ Edited by Dr. Dimitris Achilias
}

ISBN 978-953-51-0327-1

Hard cover, 406 pages

Publisher InTech

Published online 16, March, 2012

Published in print edition March, 2012

The presently common practice of wastes' land-filling is undesirable due to legislation pressures, rising costs and the poor biodegradability of commonly used materials. Therefore, recycling seems to be the best solution. The purpose of this book is to present the state-of-the-art for the recycling methods of several materials, as well as to propose potential uses of the recycled products. It targets professionals, recycling companies, researchers, academics and graduate students in the fields of waste management and polymer recycling in addition to chemical engineering, mechanical engineering, chemistry and physics. This book comprises 16 chapters covering areas such as, polymer recycling using chemical, thermo-chemical (pyrolysis) or mechanical methods, recycling of waste tires, pharmaceutical packaging and hardwood kraft pulp and potential uses of recycled wastes.

\title{
How to reference
}

In order to correctly reference this scholarly work, feel free to copy and paste the following:

Hafedh Rigane and Khaled Medhioub (2012). Valorization of Organic Wastes by Composting Process and Soil Amendment, Material Recycling - Trends and Perspectives, Dr. Dimitris Achilias (Ed.), ISBN: 978-953-510327-1, InTech, Available from: http://www.intechopen.com/books/material-recycling-trends-andperspectives/valorisation-of-wastes-by-composting-and-soil-amendment

\section{INTECH}

open science | open minds

\author{
InTech Europe \\ University Campus STeP Ri \\ Slavka Krautzeka 83/A \\ 51000 Rijeka, Croatia \\ Phone: +385 (51) 770447 \\ Fax: +385 (51) 686166 \\ www.intechopen.com
}

\author{
InTech China \\ Unit 405, Office Block, Hotel Equatorial Shanghai \\ No.65, Yan An Road (West), Shanghai, 200040, China \\ 中国上海市延安西路65号上海国际贵都大饭店办公楼 405 单元 \\ Phone: +86-21-62489820 \\ Fax: +86-21-62489821
}


(C) 2012 The Author(s). Licensee IntechOpen. This is an open access article distributed under the terms of the Creative Commons Attribution 3.0 License, which permits unrestricted use, distribution, and reproduction in any medium, provided the original work is properly cited. 